\title{
Connections in the History of Australian Computing
}

\author{
John Deane \\ Australian Computer Museum Society, \\ PO Box S-5, Homebush South, NSW 2140, Australia \\ jdeane@ihug.com.au
}

\begin{abstract}
This paper gives an overview of early Australian computing milestones up to about 1970 and demonstrates a mesh of influences. Wartime radar, initially from Britain, provided basic experience for many computing engineers. UK academic Douglas Hartree seems to have known all the early developers and he played a significant part in the first Australian computing conference. John von Neumann's two pioneering designs directly influenced four of the first Australian machines, and published US designs were taken up enthusiastically. Influences passed from Australia to the world too. Charles Hamblin's Reverse Polish Notation influenced English Electric's KDF9, and succeeding stack architecture computers. Chris Wallace contributed to English Electric, and Murray Allen worked at Control Data. Of course the Australians influenced each other: Myers, Pearcey, Ovenstone, Bennett and Allen organized conferences, interacted on projects, and created the Australian Computer Societies. Even horse racing played a role.
\end{abstract}

Keywords: Australia, computing, Myers, Pearcey, Ovenstone, Bennett, Allen, Wong, Hamblin, Hartree, Wilkes, CSIRO, CSIRAC, SILLIAC, UTECOM, WREDAC, SNOCOM, CIRRUS, ATROPOS, ARCTURUS.

\section{Introduction}

The history of computing in Australia can be seen as a nearly continuous series of personal connections, both within the country and internationally. The following sections highlight some of the influences on the early Australian projects.

\section{George Julius' Automatic Totalisator}

There have been calculating aids in Australia for as long as there have been people here, but one of the first mechanical aids associated with Australia was developed by a mechanical engineer, George Julius. George was born in England ${ }^{1}$, brought up in New Zealand, and it might be fair to say he was obsessed with mechanical gadgets. From 1896 he was working as a railway engineer in Western Australia and

\footnotetext{
${ }^{1}$ Born in Norwich, England 29 April 1873, died 28 June 1947.
} 
"A friend in the west conceived the idea of getting me to make a machine to register votes, and so to expedite elections by giving the result without any human intervention." [1]

George liked the challenge and by 1906 he had a "Voting machine"2 which he offered to the Australian Federal Government. They could see difficulties, and considerable expense, and declined. But George's advisers would not be thwarted:

"A friend who knew of a 'jam tin tote' - a machine which kept a sort of record of tickets sold at each window ... I found the problem of great interest as the perfect tote must have a mechanism capable of adding the records from a number of operators all of whom might issue a ticket on the same horse at the same instant."

George was head-hunted from the railways by a Sydney engineering firm, and also set himself up as a consulting engineer in 1907. Even with two jobs and a young family he built a prototype of his Automatic Totalisator in his home workshop [3]. ${ }^{3}$

The first Tote was installed in Auckland NZ in 1913. Though racing officials predicted that the "giant tangle of piano wires, pulleys and cast iron boxes" wouldn't work, it was a great success. George patented it in $1914,{ }^{4}$ installed the second in Western Australia in 1916, set up Automatic Totalisators Ltd. in 1917 and never looked back. By 1970 Australian Totalisators were in service in 29 countries [4].

The London Science Museum has described the Julius Tote as the "earliest online, real-time, data-processing and computation system" that the curators can identify [5].

George took part in an increasing number of engineering and scientific bodies, and when the Council for Scientific and Industrial Research (later CSIRO) was formed in 1926 he became its first Chairman [6]. The Council was formed to direct research into agriculture but by the mid 1930s Sir George became convinced that research should be extended to industry, and he was instrumental in creating the Aeronautical Research Laboratories, Electrotechnology Section, and the Radiophysics Laboratory in 1939.

\section{David Myers' CSIR Differential Analyser}

About 1925 George Julius gave a lecture on calculating machines where he demonstrated his Totalisator model [7]. In the audience 14 year old David Myers ${ }^{5}$ was very impressed, and the session generated a lifelong interest in computing machinery. David graduated from Sydney University then headed for the UK in 1933. Before starting his PhD at Oxford he briefly worked for a company constructing a mechanical "computer" (a Bush Differential Analyser) for Prof Douglas Hartree at Manchester. David used this D-A later, and maintained contact with Prof Hartree for many years.

David returned to Sydney in 1936, joined the CSIR National Standards Laboratory, and subsequently headed its new Electrotechnology Section. Instead of standards, this

\footnotetext{
${ }^{2}$ UK patent $1906 / 28,335$.

${ }^{3}$ This model is now in the Sydney Powerhouse Museum collection.

${ }^{4}$ Australian Patent 15133/14, 21 December 1914.

${ }^{5}$ Born Sydney 5 June 1911, died Sydney 11 November 1999 [8].
} 
group was soon pressed into war service developing gun aiming computer devices, and they continued this work with Radiophysics' radar group.

After WW2 David recommended increased work on computing devices and the Mathematical Instrument Section was created within his Division. Their first job was the design and construction of an advanced electro-mechanical Differential Analyser for the CSIR. This used technology developed for gun aiming, and was used heavily through the 1950s [9].

\section{Trevor Pearcey and CSIRAC}

In 1940, a young mathematician, Trevor Pearcey, ${ }^{6}$ joined the UK war effort instead of starting a PhD. He worked with the British Radar Research Establishment on the way radio signals travelled in different atmospheric conditions. Initially this involved months of work on manual calculators, but after contact with Prof Douglas Hartree the work continued on the Differential Analysers at Manchester then at Cambridge $[10,11]$.

Late in 1944 the radar research was winding down and Trevor answered a newspaper advertisement for a mathematical physicist with the CSIR Division of Radiophysics. He was successful and, a year later with the end of the war, he sailed for Australia. Trevor accommodated a growing interest in calculating machines by arranging to visit Boston and Howard Aiken's enormous Automatic Sequence Controlled Calculator at Harvard University, as well as the latest Bush Differential Analyser nearby at the Massachusetts Institute of Technology.

Trevor established a Mathematical Section in Sydney, then managed to convince management to redirect his radio studies into the development of an electronic computing machine. He argued that this would clearly be needed by Radiophysics' other projects.

The logical design work started in 1946 with radar engineer Maston Beard producing circuit details. While the influences still have to be teased out, Trevor could hardly not have known of UK and US work. In mid 1945 Prof Hartree had prepared a large report into calculating machines [12] which included extensive extracts from John von Neumann's EDVAC report [13], and outlines of the critical memory design. Anyhow, Trevor clearly approached his design from first principles, the essential design of the CSIR Mark 1 was completed in early 1948 and construction started. A review paper written then started with Charles Babbage and ended with a prediction:

"in the non-mathematical field there is scope for the use of the [computing] techniques in such things as filing systems. It is not inconceivable that an automatic encyclopaedic service operated through the national teleprinter or telephone service will one day exist." [14]

Radiophysics staff developed major sub-systems and carried out the construction. The Mark 1 ran its first program late in 1949 though the arithmetic unit was not complete [15].

While Trevor and his team worked on their computer, David Myers organised Australia's first Conference On Automatic Computing Machines for 1951. Four presentation were given by Prof Hartree, three by David Myers and four by Trevor Pearcey.

${ }^{6}$ Born London 5 March 1919, died Melbourne 27 January 1998. 
Also there was a substantial equipment display including the CSIRO Differential Analyser, manual calculators, considerable punched card equipment - and - the CSIRO Mark 1 Electronic Computer [16].

The computer was heavily used, a high-level language was developed alongside the world's first computer music program [17]. Trevor wanted to start on Mark 2 and CSIRO approached Australian industry for commercial support. This was not forthcoming and CSIRO did not want to fund computer development. After considerable agonising the Mark 1 was transferred to the University of Melbourne and renamed CSIRAC in 1956. There it provided a successful service until 1964 [18].

CSIRAC was preserved by Museum Victoria, it received Heritage Status in 2009, and is believed to be the only intact first generation computer [19].

\section{John Ovenstone and WREDAC}

Immediately after WW2, and in the shadow of German terror weapons, Britain and Australia agreed to develop rocket technology at a munitions factory north of Adelaide. A corridor was allocated from there stretching 1,800 km north-west to the ocean near Broome in WA, and this test range was christened Woomera [20].

As the Long Range Weapons Establishment (LRWE) installed tracking cameras, radar, recording equipment and started rocket test firings from 1949, it quickly became obvious that their room full of girls with desk calculators took too long to process the flight data. They knew of Trevor Pearcey's work and sent a group to the 1951 computer conference. Shortly after that they started building a copy of the CSIRO Mark 1 as the LRWE Electronic Digital Automatic Computer, or LEDAC [21].

Management had a change of heart, cancelled $L E D A C$, and directed LRWE to purchase a Ferranti Mark 1. However, the Ferranti machine wasn't ready, availability kept slipping and its price kept rising.

Also in 1951 LRWE hired a brilliant maths graduate, John Allen-Ovenstone, and sent him to Cambridge to do a doctorate under Douglas Hartree. John had used the CSIRO computer and reached Cambridge shortly after their first computer, EDSAC ${ }^{7}$, came into operation. When he returned late in 1953 nothing had changed, and he wrote a detailed specification for the computer that LRWE needed [22].

John visited the UK and found Ferranti's PEGASUS too complicated, and English Electric's DEUCE wasn't ready, but Elliotts was willing to build a special version of their 400 series. Their internal "odd jobs" code, “403", became LRWE's computer. Initially called "Cobber", then the Elliott 403, and following LRWE's name change to the Weapons Research Establishment (WRE), it was WREDAC. The CPU was shipped in mid 1955 and the output processor some months later. By late 1956 WRE$D A C$ was working well [23].

John Ovenstone managed WREDAC but he saw a much bigger picture. He organised a week long computer conference in June 1957 at WRE. There were 25 papers on programming, 23 on engineering, and from John's vision: 15 on business applications. There were demonstrations of WREDAC and their analogue computer, Elliotts'

\footnotetext{
${ }^{7}$ Electronic Delay Storage Automatic Calculator largely based on von Neumann's work [13].
} 
$A G W A C^{8}$. Presenters came from London, Cambridge, Leeds and Manchester Universities, the UK National Physical Laboratory, Ferranti, EMI, Elliotts and English Electric. Also Michigan University, the US Cape Canaveral testing ground, three Australian Universities, CSIRO and, of course, WRE. A few of the visitors were Andrew Booth, Stanley Gill, Tom Kilburn, and Maurice Wilkes. Locals including Trevor Pearcey, Murray Allen, John Bennett, Brian Swire and John Ovenstone renewed acquaintances and a great deal of information was transferred [24].

"The conference was a great success, both technically and socially" [25]

WRE hired an IBM 7090 from 1960, and in late 1962 WREDAC was scrapped [26].

\section{Brian Swire, John Bennett and SILLIAC}

In 1952 the University of Sydney's Physics Department got a new Head, Dr Harry Messel, and a new budget. Messel appointed Dr John Blatt from the University of Illinois. Dr Blatt had programmed Illinois' ILLIAC, one of a series of copies of John von Neumann's IAS Computer, and easily made the case that Physics needed a computer. Australia's only computer was on the Sydney Uni site, but it was being kept very busy with CSIRO work. Prof Messel campaigned for funding and in 1954 Adolph Basser donated his horse's Melbourne Cup winnings. Dr Blatt arranged to get circuit details and construction samples from Illinois while Prof Messel arranged for staff to build their computer and to program it [27].

Construction of "Sydney's ILLIAC", or SILLIAC, was directed by Brian Swire. Brian had worked as a radar engineer at Radiophysics then moved to the CSIRO Aeronautical Research Laboratory, and he attended the 1951 conference. He took the von Neumann/ILLIAC design and reworked it for maximum reliability [28].

When they advertised for a software expert who could also teach programming, the best applicant was an Australian working for Ferranti UK. John Bennett had experience with CSIR's radar team and David Myers before heading to the UK. He was Maurice Wilkes first $\mathrm{PhD}$ student and he had helped build Cambridge University's first computer EDSAC, which was largely based on John von Neumann's EDVAC design. John Bennett's work for Ferranti involved reworking the instruction set of their first computer, logic design (including NIMROD, the first games console), software development and customer relations [29].

SILLIAC's circuitry was constructed by Sydney electronics firm Standard Telephones and Cables then assembled and tested by Brian's small team from mid 1955. John started programming courses, which included a helping of numerical analysis concepts, and assembled the operating software based on Illinois' experience. The first successful run in July 1956 gave Sydney a brief lead in quantum theory ${ }^{9}$ and heralded a decade of intense work for the University, CSIRO and business [30].

Late in its life SILLIAC was interconnected with other University computers as an input/output server in what we would now call a local area network. Hardware and software were developed by Chris Wallace. Chris later spent some time with English Electric and contributed to their $K D F 9$ team [31].

\footnotetext{
${ }^{8}$ The Australian Guided Weapons Analogue Computer was used to model missile behavior.

${ }^{9}$ Specifically, the mathematical description of helium superfluidity.
} 
When SILLIAC was finally turned off in 1968, parts were given to a variety of people, including 14 schoolchildren who wrote in asking for mementos [32].

John Bennett continued lecturing, supporting computing as a profession and, with Trevor Pearcey, founded the Australian Computer Society.

\section{UTECOM}

At the same time as SILLIAC was being built, Sydney's other university, the New South Wales University of Technology, received a large grant from the state government to study nuclear power. The new head of Electrical Engineering, Rex Vowels, proposed purchasing a computer to support multiple disciplines [33]. Government policy meant the purchase had to be British, and in 1954 that meant a Ferranti Mark 1, Lyons LEO 1 or English Electric DEUCE. They felt that the DEUCE, derived from Alan Turing's ACE design, was the most advanced and ordered the University of Technology Electronic Computer, ie UTECOM. This was shipped from the UK in mid 1956 and it was used from September [34].

Work on UTECOM paralleled SILLIAC with intense student, research and commercial activity. An early user was Professor of Philosophy (and ex radar engineer) Charles Hamblin. At the 1957 computer conference he presented a somewhat ab struse maths method "Reverse Polish Notation" and showed how this simplified programming and even hardware design. English Electric engineers at the conference understood the significance and their next major machine, the $K D F 9$, used its pushdown/pop-up stack memory extensively [35].

UTECOM went through two rounds of upgrades and its owner changed its name to the University of NSW before it was replaced by an IBM 360 in 1966, and mostly scrapped.

\section{Murray Allen's ADA}

In 1949 the Australian government started the Snowy Mountains Hydro-electricity project. This required an unprecedented level of engineering design and, specifically, mathematical modeling of the overall system. A first attempt at this by manual calculation had taken "many man-years", and they needed to do a whole series [36].

The Snowy folk approached David Myers at the CSIRO Section for Mathematical Instruments (SMI) and found that they already had a project underway that seemed a good match. The SMI had a brilliant young engineering graduate, Murray Allen, who was developing a new computer as his $\mathrm{PhD}$ project. This used a new electronic device, the transistor, which promised speed, reliability, heat, and size advantages over vacuum-tube technology. Murray's project was to rework the US Bendix D-12 Differential Analyser design using transistors. ${ }^{10}$ This was electronic, digital, programmable and automatic - it was ADA, the Automatic Differential Analyser [37].

Construction started in 1956 when reliable transistors became commercially available. $^{11}$ Adolph Basser contributed funding and the Snowy Authority wanted $A D A-2$

\footnotetext{
10 The D-12 was based on Northrop's 1950 Magnetic Drum Digital Differential Analyzer (MADDIDA).

${ }^{11}$ Philco surface-barrier germanium transistors.
} 
for their exclusive use. $A D A$ was ceremonially opened in March 1958 - but its life was short. Its memory was a CSIRO built magnetic drum:

"One afternoon tea [early in 1961 [38]] there was a mighty crash and the drum was essentially destroyed - a piece of lint had lodged under a head and dug a great channel. ADA was done for." [39]

\section{David Wong's SNOCOM}

During the development of $A D A$ one of Sydney Uni's graduate students, David Wong, was given the task of determining what the Snowy Mountains Hydro-electric Authority (SMHA) really wanted to do, and what $A D A-2$ should be capable of. David concluded that while $A D A$ had 60 integrators, the full problem would require 400 . Also, the SMHA had many non-differential computing jobs, and he showed that while these could be expressed in differential form, it was complicated. David went one step further and programmed a representative differential problem on Sydney University's digital computer SILLIAC. His conclusion that a general-purpose computer would do, plus its specification, earned his Master's degree, and a PhD project - to build it [40].

There were some constraints on the project: little money, little time, and little help. Then, in early 1957, the design of a small commercial US computer, the LGP-30, was published by its designer, Stanley Frankel [41]. The Librascope General Purpose computer used valve logic and a drum memory and was surprisingly similar, in a general way, to $A D A$. David, with Murray Allen, set about expanding the LGP-30's description to a design they could build with the modules developed for $A D A$ [42].

A simulator for the Snowy Computer - SNOCOM - was written on SILLIAC [43] and software development started. Much was done through a $500 \mathrm{~km}$ teleprinter link from SMHA headquarters in Cooma!

SNOCOM was delivered to SMHA at Cooma in August 1960. By 1962, 50 programmers kept SNOCOM busy for two shifts a day, and it was augmented by an Elliott computer. In 1967 SNOCOM was retired to student work at Sydney Uni, then presented to the Powerhouse Museum [44].

\section{Murray Allen, Trevor Pearcey and CIRRUS}

Following the transfer of CSIRAC to the University of Melbourne a very disappointed Trevor Pearcey returned to the UK Radar Research Establishment (RRE) late in 1957. Their fast, and largely secret, vacuum-tube computer TREAC had been operating since 1953 and Trevor worked on compilers and a subroutine library stored in read-only ferrite-rod memory. He also had contact with Maurice Wilkes and the brand new EDSAC 2 at Cambridge. This also had read-only memory, here used to control instruction execution - it was the first microprogrammed computer [45, 46].

In 1959 Trevor returned to Australia and joined the CSIRAC Laboratory in Melbourne. At the same time Murray Allen left Sydney University and joined the University of Adelaide to establish their computer department. Murray got his staff and students thinking about a big computer project and he talked to Trevor and the Weapons Research computing team. Their initial goal was to produce a cheap, 
open-ended architecture with minimal hardware based around ferrite core memory and related read-only store. They dubbed the "blue sky", unfunded project CIRRUS, and proceeded to produce a detailed design. The instruction microprograms were simulated by Trevor on CSIRAC and software design started [47].

Adelaide University saw a very promising future for the design, supported the project and stimulated funding from the Postmaster General, and Weapons Research Establishment.

The basic hardware elements that Murray used in ADA and SNOCOM were extended for CIRRUS and constructed by a PMG contractor. As the hardware developed it became clear that it would be so fast that a form of multiprogramming would be needed to keep the processor busy. The team knew of a few commercial examples (Honeywell 800 and IBM 7030 Stretch) but their requirements were different. John Penny wrote a simulator on WRE's IBM 7090 and developed the operating software there [48].

CIRRUS came into operation in late 1963 with 4 user workstations. It was fast, inexpensive, and well ahead of commercial contemporaries. It was heavily used despite the installation of a CSIRO CDC 3200 and a CDC 6400. As well as teaching and research programming, special purpose on-line control and signal-processing workstations were built. A prolonged breakdown in 1969 triggered the purchase of a Data General Nova, and CIRRUS was taken out of service late in 1971 [49].

CIRRUS is preserved in Adelaide Uni's Electrical Engineering Department.

Australian industry did not take up this cheap and flexible design and Adelaide Uni did not pursue computer development. Murray Allen spent a year with Control Data in the USA contributing to the $C D C 3000$ series computers, then he moved to the University of NSW. Trevor Pearcey and John Penny joined the new CSIRO Division of Computing Research.

\section{ATROPOS}

The Weapons Research folk needed to know where the rockets they were testing were likely to come down. They had an "impact predictor" system to do this ${ }^{12}$, but with the 1958 Blue Streak project the impact point would shift by $60 \mathrm{~km}$ every second, and they decided a digital system was needed. It had to run the 5,000 instruction procedure five times a second and there wasn't a commercial system WRE could afford which would do that [50]. A small team of WRE engineers (Ian Hinckfuss, Ron Keith and Ian Macaulay) visited the UK in 1957 and included RRE where Trevor Pearcey was working on TREAC [51]. This machine was fast, with parallel operation and very good arithmetic [52]. They felt they could do even better with transistors instead of valves, and core memory instead of William's Tube CRTs.

They had a design by 1960 and WRE workshops constructed their computer by the end of 1962. This was large for a second generation machine: $6 \mathrm{~m}$ wide, $2 \mathrm{~m}$ high and $1 / 2 \mathrm{~m}$ deep. Transporting it $150 \mathrm{~km}$ from the labs near Adelaide to the Woomera Range was done on an air cushioned truck, at $15 \mathrm{~km} / \mathrm{h}$.

Its major input was from two radar units $200 \mathrm{~km}$ away, so they also had to invent a reliable data transmission system [53]. Its job was to convert radar data to position

\footnotetext{
${ }^{12}$ Rocket tracking radar was linked to plotting tables watched by the Safety Officer.
} 
and speed, carry out processing quality checks and compare the predicted impact point to the rocket range boundaries. The final stage could be to instruct an errant missile to self-destruct, so it was named after the Greek god of death, ATROPOS.

They also wrote a simulator and tested their software on WRE's IBM 7090. Then they generated test radar data there too and ATROPOS was placed in operation at the end of 1963 [54]. In 1964 it was

"one of the few, and certainly the largest real time data processing system operating in Australia. Yet with the exception of the radars and plotting tables, all the equipment involved was designed by WRE and built either in the WRE or by local industry" [55]

The system was successful and reliable, and was operated until 1974 when it was replaced by a commercial computer [56].

\section{ARCTURUS}

Following David Wong's completion of SNOCOM he built a large digital trainer, NIMBUS, and from the early 1960s started thinking about a very economical, general purpose computer for the Electrical Engineering Department at Sydney Uni. There was no budget at all but David started small related projects: a printer controller, and a remarkably fast paper tape reader. He also started salvaging electronic components and developing the design with SNOCOM style hardware. By mid 1964 he had a complete design, and a small amount of funding to build a computer for educational use [57].

David bought core memory, a paper tape punch, and the necessary components to construct his machine in the University. It was completed in 1966 at a cost around $£ 5,000$. There was also a competition to name it, and ARCTURUS ${ }^{13}$ won [58].

While there were other computers available ARCTURUS was fast and convenient, and its hardware could be modified for special projects. For example, when IBM donated a large disc drive (a RAMAC 305) in 1971, it was easiest to build an interface for ARCTURUS (which was done by Kevin Rosolen) [59].

By 1975 small and cheap commercial computers designed for digital control were available and ARCTURUS was replaced by a Digital Equipment PDP-11/45 [60].

\section{Summing Up}

History tends to make champions of inventors and early Australian computing has a notable number of inventions. This brief overview of the obvious early milestones shows quite a mesh of influences. British radar provided basic electronic techniques, the critical delay-line memory device and an excellent reason to automate calculations. UK academic Douglas Hartree knew David Myers, Trevor Pearcey and John Ovenstone. John von Neumann's two fundamental designs, EDVAC and the IAS Computer, directly influenced CSIRAC and SILLIAC, and had surprising influences on WREDAC and CIRRUS via Cambridge's EDSAC. Published US designs were

${ }^{13}$ In Greek mythology Zeus created Arcturus to guard the bear. 
interpreted for $A D A$ and SNOCOM and further British radar work on TREAC influenced CIRRUS and ATROPOS.

Influences passed out of Australia too. Charles Hamblin's applied mathematical philosophy influenced English Electric's $K D F 9$, and arguably all the succeeding stack architecture computers. Chris Wallace worked at English Electric, Trevor Pearcey contributed to TREAC and Murray Allen sojourned at Control Data. Exactly what did they contribute?

Of course the Australians influenced each other. David Myers, Trevor Pearcey, John Ovenstone, John Bennett and Murray Allen organized conferences, bounced ideas off each other, educated a generation of engineers and programmers, and did much to create the state and national computer societies.

Finally, this is part of the story up to about 1970. There is of course more, eg CSIROnet, Owen Hill's Microbee, Alan Bromley's ${ }^{14}$ part in the first build of Charles Babbage's Difference Engine and the CSIRO Wireless LAN saga!

\section{Appendix - Brief Specifications}

\begin{tabular}{|l|l|l|}
\hline System & Used & Brief Specification \\
\hline $\begin{array}{l}\text { Automatic } \\
\text { Totalisator }\end{array}$ & 1913 on & $\begin{array}{l}\text { Electro-mechanical decimal adders with smart ticket } \\
\text { machine scanners. Not programmable. }\end{array}$ \\
\hline $\begin{array}{l}\text { CSIR Diff. } \\
\text { Analyser }\end{array}$ & $\begin{array}{l}1946 \text { to } \\
\text { c.1960 }\end{array}$ & $\begin{array}{l}\text { Electro-magnetic analogue integrators. Programmed by } \\
\text { cable interconnections. }\end{array}$ \\
\hline $\begin{array}{l}\text { CSIR Mark } 1 \\
\text { (CSIRAC) }\end{array}$ & 1949 to 1964 & $\begin{array}{l}\text { Serial digital computer, vacuum tube logic, mercury } \\
\text { delay-line memory, magnetic drum, paper tape i/o. }\end{array}$ \\
\hline $\begin{array}{l}\text { WREDAC } \\
\text { (Elliott 403) }\end{array}$ & 1955 to 1962 & $\begin{array}{l}\text { Serial digital computer, vacuum tube logic, Ni delay- } \\
\text { line memory, mag. disc, mag. tape, paper tape, plotter. }\end{array}$ \\
\hline SILLIAC & 1956 to 1968 & $\begin{array}{l}\text { Parallel digital computer, vacuum tube logic, Williams' } \\
\text { tube CRT memory, magnetic tape, paper tape i/o. }\end{array}$ \\
\hline $\begin{array}{l}\text { UTECOM } \\
\text { (EE DEUCE) }\end{array}$ & 1956 to 1966 & $\begin{array}{l}\text { Serial digital computer, vacuum tube logic, mercury } \\
\text { delay-line memory, magnetic drum, punched card i/o. }\end{array}$ \\
\hline ADA & 1958 to 1961 & $\begin{array}{l}\text { Serial digital differential analyzer, transistor logic, } \\
\text { magnetic drum memory, paper tape, plotter. }\end{array}$ \\
\hline SNOCOM & 1960 to 1967 & $\begin{array}{l}\text { Serial digital computer, transistor logic, magnetic drum } \\
\text { memory, paper tape i/o. }\end{array}$ \\
\hline CIRRUS & 1963 to 1971 & $\begin{array}{l}\text { Parallel digital computer, micro-programmed transistor } \\
\text { logic, ferrite core memory, multi-programmed } \\
\text { operating software in ROM, paper tape i/o. }\end{array}$ \\
\hline ARCTURUS & 1966 to 1975 & $\begin{array}{l}\text { Parallel digital computer, transistor logic, very fast } \times, \div \\
\text { Parallel digital computer, transistor logic, ferrite core } \\
\text { memory, paper tape i/o. }\end{array}$ \\
\hline
\end{tabular}

${ }^{14}$ Born 1947, died 16 August 2002. 


\section{References}

1. Anderson, M., Cochrane, P.: Julius Poole \& Gibson: the first eighty years from Tote to CAD. Julius Poole \& Gibson, Sydney (1989)

2. ibid

3. ibid

4. Conlon, B.: Automatic Totalisators Limited - later ATL, http: / / members. ozemail. com. au/ bconlon/atl.htm (accessed 29/11/2009)

5. Swade, D.: Science Goes to the Dogs: a Sure Bet for Understanding Computers. In: New Scientist, October 29 (1987)

6. CSIRO Chairmen - April 1926 to 31 December 1945, http://www.csiro.au/resources/CSIROChairmen.html (accessed 11/11/2009)

7. Anderson, M., Cochrane, P.: ibid (1989)

8. Service for founding Vice-Chancellor. In: Agora La Trobe Uni. Alumni Assoc. Newsletter Autumn (2000),

http://www.latrobe.edu.au/alumni/agora/archives/agora_autumn $2000 . p d f$

9. Bennett, J.M., et al. (eds.): Computing in Australia: the development of a profession, pp. 9-14. Hale \& Iremonger, Sydney (1994)

10. Personal details generously provided by Frances Boyd née Pearcey (July 2004)

11. Pearcey, T.: A History of Australian Computing. Chisholm Institute of Technology, Melbourne (1988)

12. Hartree, D.: U.S. Developments in Calculating Machines, National Archives of the History of Computing NAHC/HAR/C1 (July 1945)

13. Von Neumann, J.: First Draft of a Report on the EDVAC. In: Randall, B. (ed.) 1973: The Origins of Digital Computers. Springer, New York (1945)

14. Pearcey, T.: Modern Trends in Machine Computation. Aust. J. Science X/4 Supp. (1948)

15. Pearcey, T.: ibid (1988)

16. Exhibition of Equipment and Demonstrations. In: Proceedings of Conference on Automatic Computing Machines held in the Department of Electrical Engineering, University of Sydney August 1951. CSIRO, Melbourne (April 1952)

17. Doornbusch, P.: The Music of the CSIRAC: Australia's First Computer Music. Common Ground (2005)

18. Willis, J.B., Deane, J.F.: Trevor Pearcey and the First Australian Computer: A Lost Opportunity? In: Historical Records of Australian Science. CSIRO (2006)

19. Victorian Heritage Database - CSIRAC, http://vhd.heritage.vic.gov.au/places/heritage/114928

20. Morton, P.: Fire across the desert: Woomera and the Anglo-Australian Joint Project 19461980. AGPS Press, Canberra (1989)

21. Personal recollections from Peter Goddard (2007)

22. Allen-Ovenstone, J.: Notes on data processing at LRWE. NAA A427/2/2 folio 7A (1953)

23. Morton, P.: ibid (1989)

24. WRE 1957: Data Processing and Automatic Computing Machines - Proceedings of Conference held at Weapons Research Establishment, Salisbury S.A. Commonwealth of Australia Dept. of Supply, Adelaide (June 3-8 1957)

25. Bennett, J.: Obituary for John Allen Ovenstone. In: Australian Computer Bulletin (September 1984)

26. Morton, P.: ibid (1989) 
27. Millar, D.D.: The Messel era: the story of the School of Physics and its Science Foundation within the University of Sydney, Australia. Pergamon Press, Sydney (1952-1987)

28. Professor Peter Aplin, Interview (2003)

29. Bennett, J.M.: Early Computer Days in Britain and Australia - some Autobiographical Snippets. In: IEEE Annals of the History of Computing 12/4 (1990)

30. Blatt, J.: News. In: The Nucleus 2/4, University of Sydney, Sydney (July 1956)

31. Basser Newsletter NS15. University of Sydney, March 14 (1966)

32. Brooks, G.: Memo to J. M. Bennett. University of Sydney, Sydney (June 6, 1968) (Archives Box 54)

33. Green, J.H., Woods, L.C.: Program for Education for Nuclear Engineering, Science at NSWUT. In: Australian Atomic Energy Symposium, NSWUT (1958)

34. Smart, R.G.: The Utecom Digital Computer. In: WRE 1957 ibid, pp. 104-1-104-5 (1957)

35. University News, UNSW, September 29 (1964)

36. Allen, M.: ADA - A Transistor Decimal Digital Differential Analyzer. In: WRE 1957 ibid, pp. 209-1-209-29 (1957)

37. Bennett, J.M., et al.: ibid, pp. 36-38 (1994)

38. Wong, D.G.: The Design and Construction of the Digital Computers Snocom, Nimbus and Arcturus. PhD Thesis, University of Sydney (1966)

39. Professor Murray Allen Interview (2003)

40. Wong, D.G.: The Investigations Leading to the Specification of a Digital Computer for Power System Operational Studies. ME Thesis, University of Sydney (1960)

41. Frankel, S.P.: The Logical Design of a Simple General Purpose Computer. Trans. IRE, PGEC EC-6(1) (March 1957)

42. Wong, D.G.: ibid (1966)

43. Bennett, J.M., Dakin, R.J.: Computers as an Aid in Computer Design Assessment. The Computer Journal 3(4) (1961)

44. Bennett, J.M., et al.: ibid, pp. 38-40 (1994)

45. ibid, pp. 44-49

46. Lavington, S.: Early British Computers. Manchester University Press (1980)

47. Kidman, B., Potts, R.: Paper tape and punched cards: the early history of computing and computing science at the University of Adelaide. University of Adelaide (1999)

48. Allen, M.W., Rose, G.A.: System Design of CIRRUS. In: First Conference on Automatic Computing and Data Processing in Australia. ANCCAC Sydney, p. C5.2 1 (1960)

49. Bennett, J.M., et al.: ibid, pp. 44-49 (1994)

50. Hinkfuss, I.C., Keith, R.J., Macaulay, I.J.: Design of a High Speed Parallel Solid State Digital Computer. In: Proc. IRE (September 1960)

51. Pearcey, T.: ibid (1988)

52. Lavington, S.: ibid (1980)

53. Hinkfuss, I.C.: A 1,200 baud Digital Data Transmission Scheme. In: Proc. IRE 1961 (1961)

54. Barlow, G.: A Real Time Data Processing System. In: Proc. NSW Comp. Soc. Conf. (September 1964)

55. ibid

56. Bennett, J.M., et al.: ibid, p. 125 (1994)

57. Wong, D.: ibid (1966)

58. Communication from John Bunton (2001)

59. Pearcey, T.: ibid (1988)

60. ibid 